\title{
Evaluation of Growth Parameters, Developmental Attributes and Yield of Sweet Corn (Zea mays saccharata Sturt) Hybrids under Varied Date of Sowing in Mid Hill of Meghalaya
}

\author{
Sidhartha Priyatam ${ }^{1 *}$, Lala I.P. Ray ${ }^{2}$ and Sushree Pratikshya Rani ${ }^{3}$ \\ ${ }^{1}$ College of Postgraduate Studies in Agricultural Sciences, \\ (CAU-Imphal), Umiam-793103, Meghalaya, India \\ ${ }^{3}$ Department of Agronomy Palli Siksha Bhavana, \\ Visva-Bharati, West Bengal, India \\ *Corresponding author
}

\section{A B S T R A C T}

\section{Keywords}

Hybrid sweet corn, Sowing dates, Cob yield, Stover yield, LAI

\section{Article Info}

Accepted:

18 May 2020

Available Online:

10 June 2020
A field experiment was conducted during kharif season of 2018 at the College of Agriculture, Kyrdemkulai, (Central Agricultural University, Imphal), Ri-bhoi district, Meghalaya to evaluate the sweet corn hybrids under varied date of sowing in mid hill of Meghalaya. The experiment was carried out in a split plot design with three numbers of main- plot treatments, viz., sowing date on $2^{\text {nd }}$ July $\left(\mathrm{S}_{1}\right), 12^{\text {th }}$ July $\left(\mathrm{S}_{2}\right)$ and $22^{\text {nd }}$ July $\left(\mathrm{S}_{3}\right)$ four numbers of sub- plot treatments, viz., ASKH-1 $\left(\mathrm{V}_{1}\right)$, ASKH-4 $\left(\mathrm{V}_{2}\right)$, ASKH-6 $\left(\mathrm{V}_{3}\right)$ and SWEET-77 $\left(\mathrm{V}_{4}\right)$ and replicated thrice. Among the main-plot treatments $\left(\mathrm{S}_{1}\right)$ exhibited highest cob yield $\left(6.59 \mathrm{t} \mathrm{ha}^{-1}\right)$ and stover yield $\left(9.97 \mathrm{t} \mathrm{ha}^{-1}\right)$ was significantly superior over remaining treatments. While, among the sub-plot treatments $\left(\mathrm{V}_{3}\right)$ witnessed significantly highest cob yield with $\left(6.20 \mathrm{tha}^{-1}\right)$ followed by $\left(\mathrm{V}_{1}\right)\left(5.60 \mathrm{tha}^{-1}\right),\left(\mathrm{V}_{4}\right)\left(4.89 \mathrm{tha}^{-1}\right)$ and $\left(\mathrm{V}_{2}\right)$ $\left(4.40 \mathrm{tha}^{-1}\right)$. Sowing done in $2^{\text {nd }}$ July $\left(\mathrm{S}_{1}\right)$ registered the highest LAI followed by $12^{\text {th }}$ July $\left(\mathrm{S}_{2}\right)$ and $22^{\text {nd }}$ July $\left(\mathrm{S}_{3}\right)$ at $30,45,60$ and 75 DAS. Significantly the highest LAI was witnessed by ASKH-6 $\left(\mathrm{V}_{3}\right)$ among all the sub-plot treatments of sweet corn hybrids at 30 , 45, 60 and 75 DAS. ASKH- 6 was proved to be best among all the four hybrids while $2^{\text {nd }}$ July was found to be superior among all sowing dates because further delay of sowing has negative effect on the performance of the hybrids.

\section{Introduction}

Maize (Zea mays L.) is an important multipurpose cereal crop and third most vital crop in India after rice and wheat. The corresponding figures for India are $8.85 \mathrm{M}$ ha area, 22.84 Mt production and $2.58 \mathrm{t} \mathrm{ha}^{-1}$ productivity. It is known as miracle crop and widely called as queen of cereals due to its immense yield potentiality. The diversified use of corn both as human food and animal feed make it as a remunerative crop for the farmers. Zea mays is further categorized into seven groups based on the grain characteristics. It is described as Dent corn, Flint corn, Sweet corn, Flour or Soft corn, 
popcorn, baby corn, and waxy corn. Among which sweet corn (Zea mays saccharata Sturt) is mainly grown in USA and Canada. Sweet corn (Zea mays saccharata Sturt) is introduced to India from USA. It is sweetest in flavour among all the corns. Sweet corn possesses one recessive gene which prevents the alteration of sugar into starch and the endosperm in the grains of fresh sweet corn has higher polysaccharide content at commercial maturity generally at $70 \%$ grain moisture content.

In a particular locality not all the cultivars are suitable for inclusion in the cropping system and there is a particular sowing time which offers maximum return. Keeping in view the production potential of maize in Meghalaya and high economic returns from sweet corn, there is ample scope of growing maize as sweet corn to improve economic status of poor maize growers of northeast hill regions $(\mathrm{NEH})$. This necessitates the evaluation of different sweet corn hybrids under varied date of sowing during kharif season.

\section{Materials and Methods}

The experiment was conducted at the College of Agriculture, Kyrdemkulai, (Central Agricultural University, Imphal), Ri-bhoi district, Meghalaya, during kharif 2018. Sweet corn was grown in the strongly acidic soil of Meghalaya, North east India, with four sweet corn hybrids as main treatment and three sowing dates as sub plot treatment. The field experiment was replicated thrice under Split Plot Design (SPD). Experimental plots were prepared with suitable gross plot size of $8 \mathrm{~m}^{2}(4 \mathrm{~m} \times 2 \mathrm{~m})$. Each plot was separated from other by a suitable bund of $50 \mathrm{~cm}$. Composite soil samples for determining the textural class and initial soil fertility status of the experimental field were collected from different places. The results of the analysed soil sample representing the experimental field was sandy clay in texture, strongly acidic in nature, high in organic carbon $(1.92 \%)$, low in available nitrogen $(225.79 \mathrm{~kg}$ $\left.\mathrm{ha}^{-1}\right)$, medium in available $\mathrm{P}_{2} \mathrm{O}_{5}\left(17 \mathrm{~kg} \mathrm{ha}^{-1}\right)$ and high in available $\mathrm{K}_{2} \mathrm{O}\left(242.6 \mathrm{~kg} \mathrm{ha}^{-1}\right)$ with a $\mathrm{pH}$ of 5.32 .

The field was first ploughed approximately 15 $\mathrm{cm}$ deep in the last week of June, 2018 and then levelled. Channels are made to facilitate the drainage and to avoid nutrient leaching as well as crop logging. Thereafter, the experimental field was divided in to required number of plots of $4 \mathrm{~m} \times 2 \mathrm{~m}$ (Gross plot) with a net plot size of $4.5 \mathrm{~m}^{2}$ and raised beds are made up to a height of $15 \mathrm{~cm}$ and sowing was done at proper spacing of $50 \mathrm{~cm} \times 25 \mathrm{~cm}$. 18 tonne of well decomposed FYM was added in advance of the expected date of sowing.

To maintain the required plant population thinning of plants were done after one week of germination. The yield per net plot was recorded in kilogram and then multiplies with factor 2.22 to convert the net plot yield into in to $\mathrm{tha}^{-1}$. The dry yield was obtained from the moisture content (Fresh weight basis) and shelling percentage. The available $\mathrm{N}, \mathrm{P}_{2} \mathrm{O}_{5}$, $\mathrm{K}_{2} \mathrm{O}$ in air dried soil were analysed by the standard procedure given by Subbiah and Asija (1956), Bray and Kurtz (1945) and Jackson (1973), respectively.

The plant height indicates the growth of a crop and five tagged plants were measured from the ground level up to the tip of upper most leaf of plant at 30,45,60,75 days and at harvest stage and the average height is recorded and expressed in centimetre. Leaf area index is calculated as leaf area per unit land area. Plant samples were first air dried and then were placed in oven to dry at 65 to $70^{\circ} \mathrm{C}$ for 36 to 48 hours for obtaining a constant drymatter weight. 


\section{Results and Discussion}

\section{Effect of sowing dates and hybrid on tasseling and silking}

The data on the average number of days for $50 \%$ tasseling and silking as influenced by different sowing dates (s) and hybrid $(\mathrm{H})$ are represented in (Table 1). Days to $50 \%$ tasseling and silking was influenced significantly by both main plot and sub plot treatments. The mean number of days for $50 \%$ tasseling and silking was 60.25 and 65.75 days, respectively at $2^{\text {nd }}$ July $\left(\mathrm{S}_{1}\right)$ was statistically at par with sowing date $12^{\text {th }}$ July $\left(S_{2}\right)$. Whereas, late sowing on $22^{\text {nd }}$ July significantly took the lowest number of days for tasseling and silking emergence. Whereas, among the sub-plot treatments the number of days $(58.22,64.00)$ taken by ASKH-4 $\left(\mathrm{V}_{2}\right)$ was lowest for both tasseling and silking and was at par with SWEET-77 $\left(\mathrm{V}_{4}\right)$. The highest number of days for tasseling and silking was taken by ASKH-6 $\left(\mathrm{V}_{3}\right)$ and was at par with ASKH-1 $\left(\mathrm{V}_{1}\right)$.The study of Gaile (2012) supports our findings who concluded that early sown corn needs more number of days to emerge and from emerge to silking but those days will be reduced in late sown conditions.

\section{Effect of on plant height $(\mathrm{cm})$ at different growth stages}

The data in table 2 revealed that the plant height varied significantly with both main and sub plot. Significantly the highest plant height was recorded for $S_{1}$ at 30 DAS $(57.56 \mathrm{~cm}), 45$ DAS $(137.14 \mathrm{~cm}), 60$ DAS $(171.57 \mathrm{~cm})$ and 75 DAS $(182.57 \mathrm{~cm})$ compared to others whereas the lowest height was recorded for S3 for the same interval. Similarly, among the subplots the highest plant height $(52.55,131.09$, $166.55,181.93 \mathrm{~cm})$ at each 15 days interval was recorded by ASKH-6 (H3) but it was at par with ASKH-1 (H1). The lowest plant height was recorded by ASKH-4 (H2) which was at par with Sweet-77 (H4) at all the intervals starting from 30DAS.

The extended vegetative growth period probably the cause of greater plant height which is supported by Ahmed et al (2000), Sulochana et al., (2015) and Ibrahim et al., (2000).

\section{Effect on LAI at different growth stages}

The data on leaf area index under different sowing dates and hybrids of sweet corn are presented in Table 3. Leaf area index (LAI) varied significantly among sowing dates at $30,45,60$ and 75 DAS. Sowing done in $2^{\text {nd }}$ July $\left(\mathrm{S}_{1}\right)$ registered the highest LAI followed by $12^{\text {th }}$ July $\left(\mathrm{S}_{2}\right)$ and $22^{\text {nd }}$ July $\left(\mathrm{S}_{3}\right)$ at 30,45 , 60 and 75 DAS. Leaf area index (LAI) also varied significantly among the different levels of hybrids at 30, 45, 60 and 75 DAS. Significantly the highest LAI was witnessed by ASKH-6 $\left(\mathrm{V}_{3}\right)$ among all the sub-plot treatments of sweet corn hybrids at 30, 45, 60 and 75 DAS. At 30 DAS; $V_{3}$ (1.18) was significantly higher over $V_{1}(1.10)$ followed by $\mathrm{V}_{4}(1.05)$ and $\mathrm{V}_{2}(0.99)$. Similar results are recorded for LAI at both 45, 60, and 75 DAS.

LAI resulted due to longer vegetative period as compared to late sowing dates which was similar to findings of Swanson and Wilhelm (1996). Among the subplot sweet corn hybrid ASKH-6 record high LAI over the remaining hybrids because of longer vegetative phase. Moosavi et al., (2012) reported the similar findings.

\section{Effect on dry matter accumulation per plant (g) at different growth stages}

The data registered by sweet corn on dry matter accumulation per plant in gram presented in table 4. Dry matter accumulation varied significantly among the date of sowing 
at 30, 45 and 60 DAS. However, at 75 DAS effect of sowing dates on dry matter accumulation was found to be nonsignificant. Sweet corn hybrid on $2^{\text {nd }}$ July produced significantly more dry matter at $30(10.43 \mathrm{~g})$, $45(34.04 \mathrm{~g}), 60(110.13 \mathrm{~g})$ and $75(127.33 \mathrm{~g})$ DAS.

Table.1 Effect of sowing dates and hybrid on days to 50\% tassel mergence and days to $50 \%$ silk emergence

\begin{tabular}{|c|c|c|c|}
\hline \multicolumn{2}{|l|}{ Treatments } & $\begin{array}{c}\text { Days to } 50 \% \text { tassel } \\
\text { emergence }\end{array}$ & $\begin{array}{l}\text { Days to } 50 \% \text { silk } \\
\text { emergence }\end{array}$ \\
\hline \multicolumn{4}{|c|}{ Main plot $($ Sowing date $=03$ ) } \\
\hline $2^{\text {nd }}$ July & $\left(\mathrm{S}_{1}\right)$ & 60.25 & 65.75 \\
\hline $12^{\text {th }} \mathrm{July}$ & $\left(\mathrm{S}_{2}\right)$ & 59.75 & 65.42 \\
\hline $22^{\text {nd }}$ July & $\left(\mathrm{S}_{3}\right)$ & 57.17 & 63.25 \\
\hline S.E. $(\mathrm{m}) \pm$ & & 0.37 & 0.46 \\
\hline C.D. $(\mathbf{P}=\mathbf{0 . 0 5})$ & & 1.44 & 1.80 \\
\hline \multicolumn{4}{|c|}{ Sub-plot (Hybrid = 04) } \\
\hline ASKH-1 & $\left(\mathrm{V}_{1}\right)$ & 59.33 & 65.00 \\
\hline ASKH-4 & $\left(\mathrm{V}_{2}\right)$ & 58.22 & 64.00 \\
\hline ASKH-6 & $\left(\mathrm{V}_{3}\right)$ & 59.89 & 65.67 \\
\hline SWEET-77 & $\left(\mathrm{V}_{4}\right)$ & 58.78 & 64.56 \\
\hline S.E. $(\mathbf{m}) \pm$ & & 0.34 & 0.36 \\
\hline$C . D(P=0.05)$ & & 1.00 & 1.06 \\
\hline
\end{tabular}

Table.2 Effect of sowing dates and hybrid on plant height $(\mathrm{cm})$ at different growth stages

\begin{tabular}{|c|c|c|c|c|c|}
\hline \multirow{2}{*}{\multicolumn{2}{|c|}{$\begin{array}{c}\text { Treatments } \\
\text { Main plot (Sowing date }=\mathbf{0 3} \text { ) }\end{array}$}} & \multicolumn{4}{|c|}{ Plant height $(\mathbf{c m})$} \\
\hline & & $\begin{array}{c}30 \\
\text { DAS }\end{array}$ & 45 DAS & 60 DAS & 75 DAS \\
\hline $2^{\text {nd }}$ July & $\left(\mathrm{S}_{1}\right)$ & 57.56 & 137.14 & 171.57 & 182.57 \\
\hline $12^{\text {th }}$ July & $\left(\mathrm{S}_{2}\right)$ & 46.35 & 124.15 & 159.49 & 171.68 \\
\hline $22^{\text {nd }}$ July & $\left(\mathrm{S}_{3}\right)$ & 40.66 & 116.48 & 151.44 & 164.65 \\
\hline S.E.(m) \pm & & 1.26 & 3.18 & 2.49 & 3.30 \\
\hline C.D. $(P=0.05$ & & 4.94 & 12.48 & 9.77 & 12.95 \\
\hline \multicolumn{6}{|c|}{ Sub-plot $($ Hybrid = 04) } \\
\hline ASKH-1 & $\left(\mathrm{V}_{1}\right)$ & 50.45 & 128.05 & 163.62 & 174.40 \\
\hline ASKH-4 & $\left(\mathrm{V}_{2}\right)$ & 43.37 & 118.83 & 153.85 & 166.20 \\
\hline ASKH-6 & $\left(\mathrm{V}_{3}\right)$ & 52.55 & 131.09 & 166.55 & 181.93 \\
\hline SWEET-77 & $\left(\mathrm{V}_{4}\right)$ & 46.38 & 125.71 & 159.31 & 169.33 \\
\hline S.E.(m) \pm & & 1.27 & 2.93 & 3.09 & 3.63 \\
\hline C.D $(\mathbf{P}=\mathbf{0 . 0 5})$ & & 3.77 & 8.70 & 9.19 & 10.77 \\
\hline
\end{tabular}


Table.3 Effect of sowing dates and hybrid on LAI at different growth stages

\begin{tabular}{|c|c|c|c|c|c|}
\hline \multirow{2}{*}{\multicolumn{2}{|c|}{$\begin{array}{l}\text { Treatments } \\
\text { Main plot }(\text { Sowing date }=03 \text { ) }\end{array}$}} & \multicolumn{4}{|l|}{ LAI } \\
\hline & & \multirow{2}{*}{$\begin{array}{l}30 \text { DAS } \\
1.23\end{array}$} & \multirow{2}{*}{\begin{tabular}{|l|} 
45 DAS \\
2.41
\end{tabular}} & \multirow{2}{*}{$\begin{array}{l}\text { 60 DAS } \\
4.06\end{array}$} & \multirow{2}{*}{$\begin{array}{c}75 \text { DAS } \\
3.39\end{array}$} \\
\hline $2^{\text {nd }}$ July & $\left(S_{1}\right)$ & & & & \\
\hline $12^{\text {th }} \mathrm{July}$ & $\left(\mathrm{S}_{2}\right)$ & 1.05 & 2.04 & 3.37 & 3.01 \\
\hline $22^{\text {nd }}$ July & $\left(\mathrm{S}_{3}\right)$ & 0.97 & 1.88 & 3.49 & 2.63 \\
\hline S.E.(m) \pm & & 0.03 & 0.04 & 0.06 & 0.05 \\
\hline C.D. $(P=0.05$ & & 0.10 & 0.14 & 0.25 & 0.18 \\
\hline \multicolumn{6}{|c|}{ Sub-plot $($ Hybrid $=04)$} \\
\hline ASKH-1 & $\left(\mathrm{V}_{1}\right)$ & 1.10 & 2.17 & 3.21 & 3.03 \\
\hline ASKH-4 & $\left(\mathrm{V}_{2}\right)$ & 0.99 & 1.96 & 3.21 & 2.80 \\
\hline ASKH-6 & $\left(V_{3}\right)$ & 1.18 & 2.26 & 4.12 & 3.28 \\
\hline SWEET-77 & $\left(\mathrm{V}_{4}\right)$ & 1.05 & 2.05 & 3.52 & 2.93 \\
\hline S.E. $(m) \pm$ & & 0.02 & 0.05 & 0.08 & 0.06 \\
\hline C.D $(\mathbf{P}=\mathbf{0 . 0 5})$ & & 0.07 & 0.16 & 0.25 & 0.18 \\
\hline
\end{tabular}

Table.4 Effect of sowing dates and hybrid on dry matter accumulation per plant $(\mathrm{g})$ at different growth stages

\begin{tabular}{|c|c|c|c|c|c|}
\hline \multirow{2}{*}{\multicolumn{2}{|c|}{$\begin{array}{l}\text { Treatments } \\
\text { Main plot }(\text { Sowing date }=\mathbf{0 3})\end{array}$}} & \multicolumn{4}{|c|}{ Dry matter accumulation per plant (g) } \\
\hline & & \multirow{2}{*}{\begin{tabular}{|l|}
30 DAS \\
10.43
\end{tabular}} & \multirow{2}{*}{\begin{tabular}{|l|}
45 DAS \\
34.04
\end{tabular}} & \multirow{2}{*}{$\begin{array}{l}\text { 60 DAS } \\
110.13\end{array}$} & \multirow{2}{*}{$\begin{array}{l}75 \text { DAS } \\
127.33\end{array}$} \\
\hline $2^{\text {nd }}$ July & $\left(\mathrm{S}_{1}\right)$ & & & & \\
\hline $12^{\text {th }}$ July & $\left(\mathrm{S}_{2}\right)$ & 7.56 & 30.00 & 102.88 & 120.63 \\
\hline $22^{\text {nd }}$ July & $\left(\mathrm{S}_{3}\right)$ & 4.79 & 23.23 & 97.69 & 113.62 \\
\hline S.E.(m) \pm & & 0.18 & 0.85 & 2.30 & 2.86 \\
\hline C.D. $(\mathbf{P}=\mathbf{0 . 0 5})$ & & 0.72 & 3.34 & 9.02 & NS \\
\hline \multicolumn{6}{|c|}{ Sub-plot $($ Hybrid $=04)$} \\
\hline ASKH-1 & $\left(\mathrm{V}_{1}\right)$ & 8.22 & 29.97 & 104.51 & 122.17 \\
\hline ASKH-4 & $\left(\mathrm{V}_{2}\right)$ & 6.02 & 26.44 & 97.44 & 112.63 \\
\hline ASKH-6 & $\left(\mathrm{V}_{3}\right)$ & 9.36 & 31.94 & 111.49 & 129.53 \\
\hline SWEET-77 & $\left(\mathrm{V}_{4}\right)$ & 6.77 & 27.99 & 100.81 & 117.76 \\
\hline S.E. $(m) \pm$ & & 0.24 & 0.84 & 2.45 & 2.48 \\
\hline $\mathrm{C} . \mathrm{D}(\mathrm{P}=0.05)$ & & 0.71 & 2.48 & 7.28 & 7.36 \\
\hline
\end{tabular}


Table.5 Effect of on cob yield, stover yield, and dry yield of sweet corn

\begin{tabular}{|c|c|c|c|}
\hline Treatments & $\begin{array}{c}\text { Cob yield } \\
\left(\text { tonne ha } \mathbf{h a}^{-1}\right)\end{array}$ & $\begin{array}{l}\text { Stover yield } \\
\left(\text { tonne ha }{ }^{-1}\right)\end{array}$ & $\begin{array}{c}\text { Dry yield } \\
\left(\text { tonne ha }{ }^{-1}\right)\end{array}$ \\
\hline \multicolumn{4}{|c|}{ Main plot $($ Sowing date $=03$ ) } \\
\hline $2^{\text {nd }}$ July $\quad\left(\mathrm{S}_{1}\right)$ & 6.59 & 9.97 & 2.44 \\
\hline $12^{\text {th }}$ July & 5.36 & 8.54 & 1.87 \\
\hline $22^{\text {nd }}$ July & 3.87 & 6.71 & 1.39 \\
\hline S.E.(m) \pm & 0.129 & 0.224 & 0.05 \\
\hline C.D. $(P=0.05)$ & 0.507 & 0.878 & 0.196 \\
\hline \multicolumn{4}{|l|}{ Sub-plot (Hybrid = 04) } \\
\hline ASKH-1 $\quad\left(\mathrm{V}_{1}\right)$ & 5.60 & 8.65 & 2.04 \\
\hline ASKH-4 & 4.40 & 7.44 & 1.50 \\
\hline ASKH-6 & 6.20 & 9.25 & 3.34 \\
\hline SWEET-77 & 4.89 & 8.28 & 1.73 \\
\hline S.E.(m) \pm & 0.148 & 0.231 & 0.055 \\
\hline C.D $(P=0.05)$ & 0.439 & 0.687 & 0.162 \\
\hline
\end{tabular}

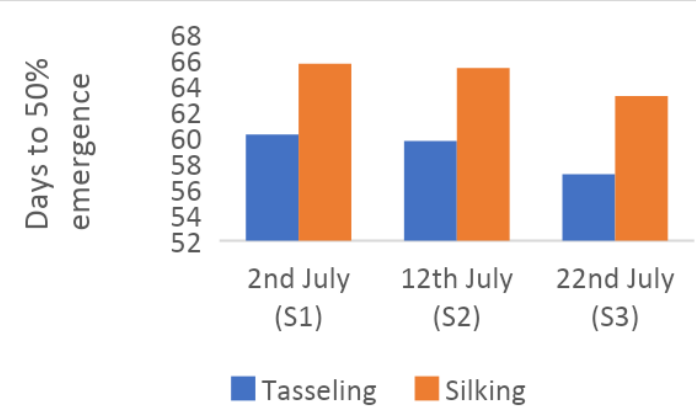

Fig.1.1 Effect of sowing dates on days to tassel and silk emergence

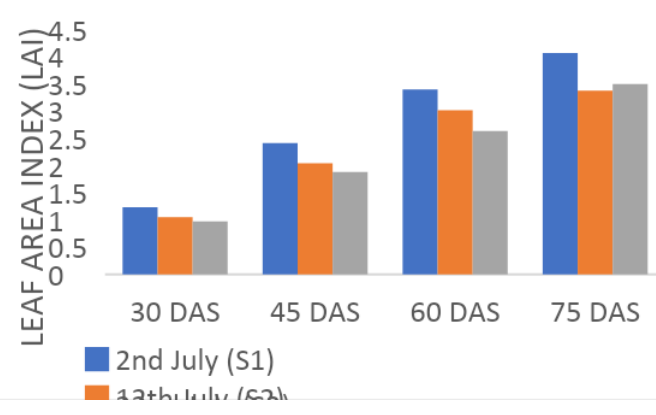

Fig.2.1 Effect of sowing dates on LAI

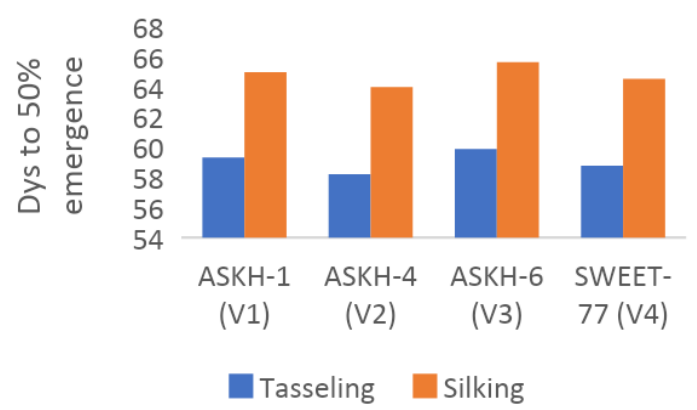

Fig.1.2 Effect of hybrid on days to tassel and silk emergence

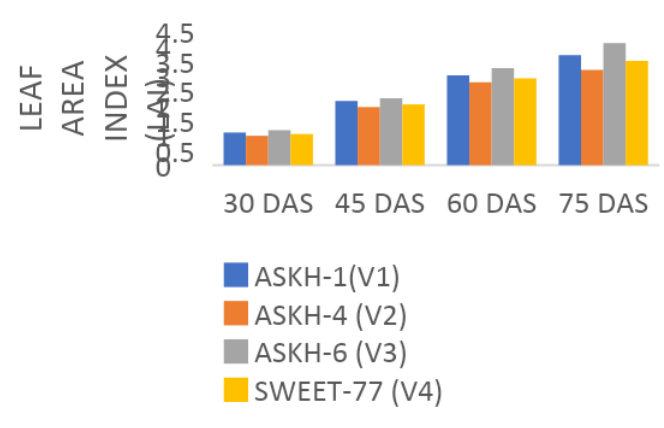

Fig.2.2 Effect of hybrids on LAI 


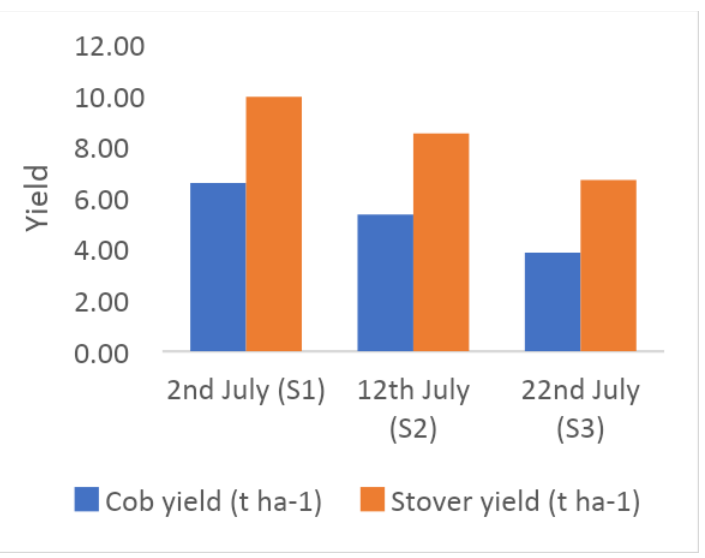

Fig.3.1 Effect of sowing date on cob and stover yield

The data obtained from the subplot treatments on dry matter accumulation was found to be significant at different stages of the crop growth. At 30DAS, $\mathrm{V}_{3} \quad(9.36 \mathrm{~g})$ had significantly higher dry matter accumulation over $\mathrm{V}_{1}(8.22 \mathrm{~g}), \mathrm{V}_{4}(6.77 \mathrm{~g})$ and $\mathrm{V}_{2}(6.02 \mathrm{~g})$. Similarly, trend of dry matter accumulation was observed at 45, 60 and 75DAS. However, the sweetcorn hybrid ASKH-6 (V3) was found significantly superior to other hybrids. The higher leaf area and LAI which is the source of supplement of photosynthesis largely responsible for higher dry matter accumulation. Those findings are alike to the results of Sulochana et al., (2015).

\section{Effect of sowing dates and hybrid on cob yield, stover yield, and dry yield of sweet corn}

Significant variation was witnessed among sowing dates regarding grain yield of sweet corn. While, it also varied significantly among the hybrids (Table 5). Among the main-plot treatments sowing on $2^{\text {nd }}$ July $\left(S_{1}\right)$ $\left(6.59 \mathrm{t} \mathrm{ha}^{-1}\right)$ exhibited highest grain yield and was significantly superior over remaining treatments. It was followed by $S_{2}\left(5.36 \mathrm{t} \mathrm{ha}^{-1}\right)$ and $\mathrm{S}_{3}$ (3.87 $\left.\mathrm{t} \mathrm{ha}^{-1}\right)$. Among the sub-plot treatments ASKH-6 $\left(\mathrm{V}_{3}\right)$ witnessed significantly highest cob yield with (6.20

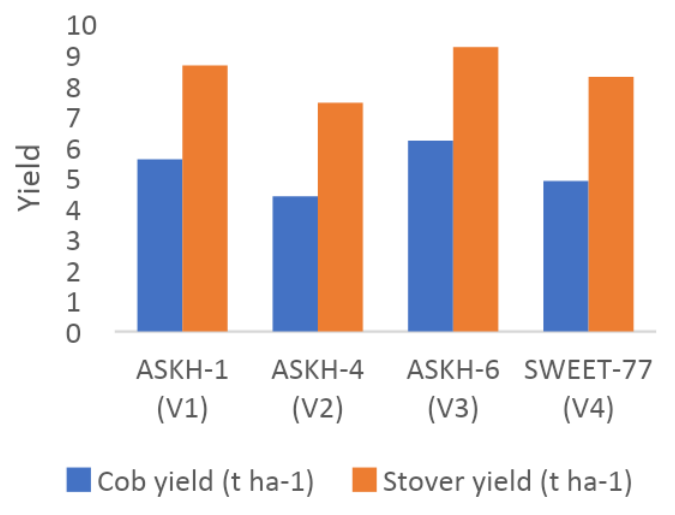

Fig.3.2 Effect of hybrids on cob and stover yield

$\left.\mathrm{t} \mathrm{ha}^{-1}\right)$ followed by ASKH-1 $\left(\mathrm{V}_{1}\right)\left(5.60 \mathrm{t} \mathrm{ha}^{-1}\right)$, SWEET-77 $\left(\mathrm{V}_{4}\right)$ (4.89 $\left.\mathrm{t} \mathrm{ha}^{-1}\right)$ and $\mathrm{V}_{2}(4.40 \mathrm{t}$ $\left.\mathrm{ha}^{-1}\right)$. At delayed planting reduction in LAI and dry matter accumulation due to shorter vegetative stage and poor partitioning of dry matter in sink might be responsible for lower values of yield attributes. Kolo et al., (2012) confirm the findings. Due to decrease in dry matter partitioning to grain and number of kernel per row, grain yield decreases in late sown conditions as suggested by Cirilo and Andrade, 1994.

Among the main-plot treatments sowing on $2^{\text {nd }}$ July $\left(\mathrm{S}_{1}\right)\left(9.97 \mathrm{t} \mathrm{ha}^{-1}\right)$ reported highest stover yield and was significantly superior over remaining treatments. While it was followed by $S_{2}\left(8.54 \mathrm{t} \mathrm{ha}^{-1}\right)$ and $S_{3}\left(6.71 \mathrm{t} \mathrm{ha}^{-}\right.$ $\left.{ }^{1}\right)$. The sub-plot treatment ASKH-6 $\left(\mathrm{V}_{3}\right)$ also recorded significantly highest stover yield (9.25 $\left.\mathrm{t} \mathrm{ha}^{-1}\right)$ and was at par ASKH-1 $\left(\mathrm{V}_{1}\right)$ $\left(8.65 \mathrm{t} \mathrm{ha}^{-1}\right)$. While SWEET-77 $\left(\mathrm{V}_{4)}\right)$ registered higher $\left(8.28\right.$ tha $\left.^{-1}\right)$ stover yield than $\mathrm{V}_{2}\left(7.44 \mathrm{t} \mathrm{ha}^{-1}\right)$.

In conclusion, the experiment was carried out to detect the best sowing date and finest hybrid of sweet corn and their combination outcomes under mid hills of Meghalaya. From the present investigation the following conclusions may be drawn that among the 
sowing date treatments significant variation as observed in the yield, therefore, early sowing on $2^{\text {nd }}$ July may be preferred over the others and among the hybrids highest yield was given by ASKH-6 $\left(\mathrm{V}_{3}\right)$.

\section{References}

Ahmad, N., Waheed, A., and Hamid, F.S. 2000. Performance of maize cultivars under late sowing conditions. Pakistan Journal of Biological Sciences, 3(12): 2098-2100.

Bray, R.H. and Kurtz, L.T. 1945. Determination of total, organic and available forms of phosphorus in soils. Soil Sci., 59: 39-45.

Cirilo, A.G., \& Andrade, F.H. 1994. Sowing date and maize productivity: I. Crop growth and dry matter partitioning. Crop science, 34(4): 1039-1043.

Gaile, Z. 2012. Maize (Zea mays L.) response to sowing timing under agro-climatic conditions of Latvia. Zemdirbyste Agriculture, 99(1): 31-40.

Ibrahim, K. Amans, A. and Abubakar, I. U. 2000. Growth indices and yield of Tomato (Lycopesicon esculentum karest) varieties as influenced by crop spacing at samaru. Proceedings of the 18th HORTSON Conference Proceedings (1): 40-47.
Jackson, M.L. 1973 Soil chemical analysis. Prentice hall of India Pvt. Ltd. New delhi. Pp. 186-192.

Kolo, E., Takim, F.O., and Fadayomi, O. 2012. Influence of planting date and weed management practice on weed emergence, growth, and yield of maize (Zea mays L.) in southern Guinea savanna of Nigeria. Journal of Agriculture and Biodiversity Research, 1(3): 33-42.

Moosavi, S.G., Mohamad, J.S., and Ali, M. 2012. Effect of planting date and plant density on morphological traits, LAI and forage corn (Sc. 370) yield in second cultivation. International Research Journal of Applied and Basic Sciences, 3(1): 57-63.

Subbiah, B.V. and Asija, G.L. 1956. A rapid procedure for the determination of available nitrogen in soil. Current Sci., 25: 259-260.

Sulochana., Solanki, N.S., Dhewa, J.S. and BajIa, R. 2015. Effect of sowing dates on growth, phenology and agro meteorological indices for maize varieties. The Bioscan, 10(3): 13391343.

Swanson, S.P., \& Wilhelm, W.W. 1996. Planting date and residue rate effects on growth, partitioning, and yield of corn. Agronomy journal, 88(2): 205-210.

\section{How to cite this article:}

Sidhartha Priyatam, Lala I.P. Ray and Sushree Pratikshya Rani. 2020. Evaluation of Growth Parameters, Developmental Attributes and Yield of Sweet Corn (Zea mays saccharata Sturt) Hybrids under Varied Date of Sowing in Mid Hill of Meghalaya. Int.J.Curr.Microbiol.App.Sci. 9(06): 2268-2275. doi: https://doi.org/10.20546/ijcmas.2020.906.277 